\title{
Gruppkultur som hinder och möjlighet för intervention vid samarbetssvårigheter. En studie av social omsorgs- och vårdpersonal inom äldre- och handikappomsorg
}

\author{
BERITH WESTMAN, MARIANNE FORSGÄRDE \& \\ LENNART NYGREN
}

\begin{abstract}
Artikeln redovisar en studie av ett interventionsförsök för att förbättra samarbetet mellan social omsorgs- och vairdpersonal inom äldre- och handikappomsorgen. Interventionen bestod av systematiska gruppdiskussioner med etiskt innehåll. I den delstudie som här redovisas visas att gruppkulturen påverkar möjligheterna att lyckas med interventionen. Detta resultat diskuteras i artikeln med hjälp av Wilfred Bions gruppteori.
\end{abstract}

\section{Introduktion}

Den studie som redovisas i denna artikel genomfördes efter ädelreformens genomförande i Sverige (Prop 1990/91:14). Denna reform resulterade bland annat $i$ att sjuksköterskor anställdes i kommunerna för att

Berith Westman och Marianne Forsgärde är fil.dr i socialt arbete, Lennart Nygren är professor. tillgodose vård för äldre- och funktionshindrade personer. En följd av detta blev att personal med social utbildning, till exempel social omsorgsutbildning, kom att ingå i samma personalgrupp som personal med vårdutbildning, med ett gemensamt ansvar för de boende. Det har visat sig att denna nya sammansättning av personal med olika utbildningsbakgrund medförde problem (Socialstyrelsen 1996:2, SOU 1997:51). 
I den kommun där föreliggande studie genomfördes hade personalen aviserat att konflikter och samarbetssvårigheter förelåg mellan social omsorgs- och vårdpersonal. Detta var motivet till att det genomfördes en serie gruppdiskussioner med personal i ett antal särskilda boenden. Ett antal delstudier genomfördes som på olika sätt studerade konsekvenserna av dessa gruppdiskussioner. De delstudier som innefattade intervjuer och enkäter med gruppdeltagarna visade marginella, vaga eller subtila förändringar efter gruppdiskussionerna (Forsgärde et al 2000, Forsgärde et al manus, Westman et al manus). I samband med genomförandet av gruppdiskussionerna gjordes även observationer av grupperna. Dessa observationer ligger till grund för innehållet i denna artikel och innebär ett närmare studium av den betydelse gruppen har för att tillgodogöra sig interventionen. Mer specifikt har artikeln syftet att belysa personalgruppernas kommunikation som en faktor bakom de marginella skillnader som erhölls som resultat i övriga delstudier.

\section{Det komplicerade studiet av grupper}

Grupper som består av personal med olika utbildningsbakgrund och som arbetar med människor med mycket varierande omsorgs- och vårdbehov är naturligtvis inte påverkbara på något enkelt, rätlinjigt sätt. Med tanke på att dessa grupper dels byter medlemmar relativt ofta, dels befinner sig i en organisation som ofta förändras, är det ingen överdrift att påstå att vi har att göra med ett studieobjekt som är mycket komplicerat att studera (jfr Hartley 1996). Olsson (1998) menar att det är rimligt att ställa sig frågan vad det är som händer både inom och mellan människor när de kommer samman i en grupp. Olsson menar att det försiggår något $\mathrm{i}$ gruppen som varken iakttagare eller gruppmedlem på ett enkelt sätt kan få kunskap om. För att förstå gruppskeenden kan vi till exempel söka kunskap $i$ individens och gruppens processer, gruppens frigörande eller hämmande funktion för individen samt gruppens sociala liv och arbetsliv (ibid). I en översikt över forskning om kommunikation i organisationer visar Jablin och Putman (2000) att man vanligen tagit utgångspunkt $\mathrm{i}$ tre olika aspekter av organisationer: kontexten, dvs. den inre och yttre miljön, strukturen, dvs. man undersöker mönster i det ömsesidiga beroendet hos organisationens olika delar, samt processen som handlar om kommunikationsbeteende $i$ organisationer.

När det gäller kontext visar Cheney och Thoger Christensen (2000) att kommunikation $i$ en organisation baseras på en rad paradoxer. En av dessa utgörs av att inre och yttre kommunikation påverkar varandra, exempelvis kan för mycket information och kommunikation (explosion) leda till "implosion" bland mottagarna, i den meningen att det blir svårigheter att ta emot kommunikationen. En annan paradox är att ett alltför öppet organisationssystem saknar identifikation eller viktiga referenspunkter vilket medför att möjligheten till särskiljande från omvärlden saknas. I ett alltför slutet system upphör alla referensmöjligheter och organisationen blir frikopplad från omvärlden.

Inom strukturaspekten är ett vanligt 
synsätt inom forskningen att man ser ett samband mellan organisationens strukturella, formella beskaffenhet och olika kommunikations-beteenden och aktiviteter (Jablin 1992 s 413). Inom processaspekten, slutligen, visar forskning bland annat att utvecklingen av kommunikationskompetens sker på såväl individ-, grupp- som organisationsnivå. Kommunikationskompetens påverkas av och påverkar också de olika system som organisationsmiljön består av (Jablin \& Sias 2000).

Som framgått är det alltså många och komplexa faktorer som kan ha betydelse för hur grupper fungerar. Även om vi varit medvetna om betydelsen av såväl kontextuella som strukturella faktorer har vi i denna delstudie med dess grund i observationsdata främst betonat processuella faktorer och sättet att kommunicera. Det är också inom ramen för detta synsätt som vi valt att diskutera observationerna med hjälp av Bions gruppteori (1974). Det finns tidigare exempel på denna slags tilllämpning av Bions teori inom forskning som är näraliggande vår ansats. Stein (1996) ger en översikt av forskning om omedvetna fenomen $i$ arbetsgrupper där bland annat Bions gruppteori ingår. Ett exempel där vårdklimatet studerats, vilket ligger nära vår ansats att studera gruppkultur är Armelius och Fogelstam (1992) som i sin studie använt Bions gruppteori. Processer i arbetslag känneteckens av en fortgående pendling mellan arbetsgruppsaktivitet och en omedveten emotionell aktivitet, bestående av beroende-, parbildning- eller kamp/flykt aktivitet (Bion 1974).

\section{Interprofessionella grupper inom social omsorg, vård och utbildning}

Forskning visar att primärvårdsgrupper som består av vårdpersonal med olika kompetenser ökar gruppens effektivitet och förbättrar personalens förhållningssätt och kvalitet för de vårdbehövande (Poulton 1995) likväl som att personalens motivation ökar (Wood et al 1994). Wilson och While (1998) menar att en bidragande orsak till att samarbetet kan bli komplicerat är att social omsorgs- och vårdpersonal har utbildningar med olika ideologiska och kulturöverförande funktioner. Netting och William (1996) visar att socialt utbildad personal tar ställning för patientens självbestämmande och därför upplever ansträngda relationer till vårdutbildad personal i de fall där de är av annan uppfattning. Vidare finns studier som visar att sjuksköterskors värderingar är mer individualistiska medan socialarbetares värderingar är kollektivistiska, strukturella och politiska (Wilmot 1995). Detta betyder att en grupp som består av personal med olika kompetenser kan vara kompletterande och utvecklande, samtidigt som olikheterna kan utgöra en grund för konflikter.

För att komma till rätta med uppkomna konflikter kan interprofessionella gruppdiskussioner utgöra ett sätt att synliggöra de olika synsätten och på så sätt främja utvecklingen mot en gemensam värdebas i arbetet (jfr Corey et al 1998, Norberg et al 1998). Det har visat sig att gruppdiskussioner bland personal inom psykiatrisk verksamhet är viktiga för att befrämja förståelse 
och att de ger möjligheter till en kontinuerlig samarbetsutbildning (Altschul 1964). Med tanke på att det inom många samhällsområden sker arbete i professionella arbetsgrupper, finns det förhållandevis lite forskning som behandlar hanteringen av professionskonflikter via olika insatser på gruppnivå.

Exempel på studier som visar komplexiteten med att arbeta med grupper i syfte att minska konflikter eller utveckla praktik kan hämtas från till exempel sjuksköterskeprofessionen där betydelsen av reflektion i grupp under de senaste åren rönt ett växande intresse (Platzer et al 2000). För att diskussioner i en grupp ska vara utvecklande anges flera aspekter som är av betydelse. Studier visar att när relationerna inom gruppen är spända och överhettade blir inlärningen omintetgjord och att bättre förutsättningar ges om kulturen i gruppen är tillåtande (Winship \& Hardy 1999). Det är alltså inte tillräckligt att enbart fokusera på den reflektion som sker i samtalsgrupperna utan det krävs också en medvetenhet om grupprocesser eftersom gruppen kan väcka bortträngd ångest som påverkar personalens jaguppfattning och kontakt med patienterna (Haddock 1996).

Ett annat exempel som visar komplexiteten kan hämtas från undervisningsområdet. En studie med frivilliga samtalsgrupper bland studenter visade att i de grupper som inte fungerade bra upplevde man sig tvingad att delta, medan i de grupper som fungerade upplevdes deltagandet vara frivilligt (Platzer et al 2000). En annan studie från detta område pekar på den betydelse träffarnas kontinuitet har. Cook och Matheson (1995) menar att brist på kontinuitet ledde till att såväl studenter som handledare upplevde otillfredsställelse och problem i grupperna.

Sammantaget menar vi att det måste finnas en medvetenhet om betydelsen av såväl yttre (kontinuitet etc.) som inre villkor (kommunikativa grupprocesser) för att komma tillrätta med samarbetssvårigheter via insatser på gruppnivå. Vårt val att genomföra observationer i de diskussionsgrupper som ingår i studien är betingat av intresset att få kunskap om, i första hand, gruppernas inre villkor. Utfallet av den typ av gruppdiskussioner som genomfördes inom ramen för denna studie är med utgångspunkt i ovanstående referenser till gruppteori och forskning om liknande interventioner, rimligen starkt beroende av dessa inre villkor.

\section{Diskussionsgrupperna som ingår i studien}

Interventionen bestod av systematiska diskussionsgrupper där personalgruppen vid fyra särskilda boenden (ett gruppboende för personer med utvecklingsstörning, ett gruppboende för personer med demenssjukdom, ett ålderdomshem och ett sjukhem) diskuterade problematiska situationer i vardagsarbetet. En diskussionsmanual (opublicerad) användes för att skapa ett utgångsläge för diskussionerna samt för att möjliggöra reflektion som öppnar upp perspektiv på det som diskuterades. De teoretiska dimensionerna i manualen exemplifierades med de problematiska situationer som personalen berättat om i den första intervjun (Westman et al manus). Diskussionsmanualen har sin fokus på etik och 
inrymmer områden som: "att bli medveten om sin egen omsorgsfilosofi", "att ge och ta emot bekräftelse», "vara god och ärlig» och satt samordna en gemensam omsorgsfilosofi». Avsikten med interventionen var att personalen skulle komma samman och reflektera över sin egen attityd, lyssna in andras och på så sätt skulle förståelsen mellan de olika professionsgrupperna utvecklas. Inför varje sammankomst förväntades att personalen skulle ha läst valda delar ur manualen. Diskussionerna genomfördes 6-8 gånger i respektive grupp under en tidsperiod av 7-15 månader. Varje sammankomst varade 2-3 timmar och var förlagd till ett avskilt rum på arbetsplatsen. Artikelns första och andra författare hade ansvar för två diskussionsgrupper vardera. Inför varje diskussionstillfälle utformade författarna frågeställningar och förslag till uppläggning som diskuterades med personalledaren. Personalledaren ansvarade i sin tur för genomförandet av de systematiska diskussionsgrupperna.

\section{Resultat från andra delstudier inom studien}

Genom att kombinera olika metoder i ett antal delstudier har vi försökt fånga interventionens betydelse. En enkätundersökning genomfördes med all personal i de fyra personalgrupper som genomfört systematiska gruppdiskussioner, experimentgrupper (EG) och i de fyra personalgrupper som enbart deltog som referensgrupper (RG). Arbetsklimatet studerades före och efter interventionen med frågor som rörde känsla av sammanhang, arbetstillfredsställelse och utbränning bland personalen. Resultatet visar att personalen hade hög anpassningskapacitet, upplevde tillfredsställelse i arbetet och hade låg nivå av utbränning redan före interventionen (Forsgärde et al 2000).

Före och efter interventionen genomfördes även intervjuer med personal i EG och i RG om deras upplevelse av problematiska situationer i vardagsarbetet. Efter interventionen visade analys av innehållet i intervjuerna likvärdiga förändringar i EG och RG. Personalen upplevde att medarbetare i mindre utsträckning utgjorde hinder och att de tidigare upplevda barriärerna mellan social omsorgs- och vårdpersonal inte längre påtalades (Westman et al manus).

Intervjuerna tolkades även fenomenologiskt-hermeneutiskt där innebörden i RGs berättelser var likvärdiga med berättelserna som erhölls före interventionen. Tolkningen visade att EGs berättelser förändrats från tillbakavisande till bekräftande kommunikation mellan medarbetare. Mer subtila förändringar som pekade mot en känslomässig närhet med försök att förstå medarbetares perspektiv och reaktioner synliggjordes också. Tolkningen visade dessutom att efter interventionen var det inte längre medarbetare utan de boende som utgjorde fokus i berättelserna (Forsgärde et al manus).

\section{Metod}

\section{Urval och deltagande}

Urvalet av de särskilda boendeformerna utfördes i två steg. I första steget genomförde kommunens äldreomsorgsplanerare ett strategiskt urval av tio särskilda boendeformer (av totalt 49) utifrån kriterierna 
att de skulle vara inriktade mot olika målgrupper med ett likvärdigt antal anställda. I nästa steg informerade artikelns två första författare personalledarna vid dessa boendeformer både muntligt och skriftligt om studien. Personalledarna ansvarade för att personalgrupperna fick likvärdig information för att möjliggöra deras ställningstagande om ett deltagande i studien. Vi besökte de personalgrupper som ställde sig positiva till deltagande för vidare information och diskussion. Detta resulterade i att personalgrupper från ett gruppboende för personer med utvecklingsstörning, ett gruppboende för personer med demenssjukdom, ett ålderdomshem och ett sjukhem valde att delta i interventionen. Personalkategorierna bestod av personalledare, sjuksköterskor, undersköterskor, vårdbiträden och vårdarinnor. Gruppernas storlek varierade mellan 10 och 14 personer. Personalgrupper vid fyra särskilda boendeformer valde att delta som referensgrupper och de övriga valde att inte delta i studien.

\section{Observationer}

Under den period (1997-1999) som systematiska diskussionsgrupper pågick observerades varje personalgrupp vid tre tillfällen av artikelns två första författare; i ett tidigt skede, ungefär i mitten respektive mot slutet av gruppverksamheten. Observationerna varade under hela den tid (två till tre timmar) som diskussionsgrupperna var samlade, och den totala observationstiden i varje grupp blev därmed sex till nio timmar. Vid observationstillfällena intog vi rollen som perifer deltagare (Adler \& Adler 1994). Observationerna var öppna vilket innebar att vi satt vid sidan om diskussionsgruppen och förde anteckningar. En förutsättning för att genomföra öppna observationer är enligt Polit och Hungler (1999) att observatören får tillträde till den grupp som ska observeras och att gruppen känner tillit till observatören. Holme och Solvang (1991) förespråkar att observatören först måste erhålla bra relationer till enstaka personer $\mathrm{i}$ gruppen för att sedan bygga upp tilliten till gruppen som helhet. I vårt fall hade vi lärt känna enstaka personer i grupperna eftersom intervjuer genomförts i ett tidigare skede för att samla material till den manual som användes som underlag för gruppsamtalen. Dessutom besökte och informerade vi personalgruppen på respektive arbetsplats innan studien påbörjades. Under dessa besök upplevde vi att den personal som tidigare intervjuats "backade upp" oss inför medarbetare. Som observatörer var vi väl förtrogna med den miljö vi studerade (jfr Svensson \& Starrin 1996) där vår sociala kompetens och våra praktiska erfarenheter från liknande verksamheter medförde att vi kunde skapa goda kontakter med personalgrupperna. Polit och Hungler (1999) menar att om gruppen inte har tillit till observatören ökar risken att gruppen visar upp en fasad som ger en ytlig och förvanskad bild. Vårt bestämda intryck är att personalgrupperna accepterade oss som observatörer. $\mathrm{Vi}$ är dock medvetna om att genom att vi har funnits med i grupperna så har vi påverkat både innehållet och processen på olika sätt ( jfr Holme \& Solvang 1991) utan att vi för den skull kan redogöra för hur det har gått till eller hur det möjligtvis kan ha påverkat diskussionerna.

Observationsansatsen var ostrukturerad

Westman, Forsgärde \& Nygren: Gruppkultur som hinder och möjlighet för intervention ... 
(Polit \& Hungler 1999) och genom att hålla alla sinnen öppna ville vi försöka fånga så mycket som möjligt av det som utspelades i diskussionsgrupperna (jfr Svensson \& Starrin 1996). Dokumentationen från observationerna innehöll förutom dag, tid och antal närvarande personer en detaljerad redogörelse för allt som uttrycktes i ord. Vi skrev också ned hur vi uppfattade klimatet och händelser i gruppen, till exempel om någon läste högt ur diskussionsmanualen eller om någon gick ut. Med hjälp av ordbehandlare skrev vi så snart som möjligt ut anteckningarna medan vi fortfarande hade diskussionerna i färskt minne. Detta för att undvika att vår upplevelse från observationen skulle gå förlorad. Utskriften omfattade 9-22 sidor från respektive diskussionsgrupp.

Den totala observationstiden (mellan sex och nio timmar) i respektive diskussionsgrupp kan betraktas som en relativt begränsad tid (jfr Svensson \& Starrin 1996). Men med vald design och med en väl avgränsad och tillfällig aktivitet menar vi att vi fått ett förhållandevis rikligt och därmed tillfredsställande underlag för den genomförda analysen. En annan möjlig begränsning är att observationerna genomfördes av två olika personer. Vid första observationstillfället var vi två observatörer i samma grupp. När vi efteråt jämförde anteckningar visade de likvärdigt innehåll. Med risk för att vi skulle utgöra »ett störande» inslag i en liten personalgrupp valde vi fortsättningsvis att vara en observatör närvarande vid respektive observationstillfälle.

\section{Analysmetod}

Data från observationerna bearbetades och analyserades med inspiration av Burnard (1991, 1996) och Morgan (1993). Vi valde först att analysera varje observationstillfälle var för sig för att kunna se eventuella skillnader mellan grupperna och för att se förändringar i respektive grupp över tid. Därefter analyserades observationerna utifrån respektive diskussionsgrupp där vi letade efter utmärkande drag (jfr Miles \& Huberman 1994) i diskussionerna. Resultatet av analysen har vuxit fram ur en dialog mellan första och andra författaren. Ett första steg i analysen innebar att anteckningarna lästes $i$ sin helhet och kodades öppet (Burnard 1991) för skapandet av kategorier gällande vad som diskuterats. Texten lästes igenom ett flertal gånger till dess att all text var placerad i en kategori och de slutliga kategorierna (tio) var formulerade. Kategoriernas innehåll särskiljer sig helt från varandra (jfr Patton 1990). Analysen av det som diskuterats låg till grund för ett andra steg där vi identifierade gruppernas diskussionsnivå utifrån hur personalen lyckades anknyta och reflektera till innehållet i diskussionsmanualen. De fyra grupperna jämfördes och resultatet indelades i tre olika nivåer: djup, medel och ytlig. Våra egna intryck och reflektioner från observationerna, det som diskuterades och diskussionsnivån utgjorde underlag för den slutliga analysen.

\section{Resultat}

De fyra diskussionsgrupperna visar genomgående olikheter i såväl innehåll som diskussionsnivå. De likheter som synliggörs i kategorierna består av att medarbetare, personalen själva, boende och närstående 
utgör fokus i diskussionerna. Olikheterna däremot består av att diskussionerna i grupperna kännetecknas av positiva eller negativa attityder gentemot de olika aktörerna. I den här delen kommer vi att beskriva resultatet från varje diskussionsgrupp var för sig. Vi inleder med att beskriva innehållskategorierna och därefter diskussionsnivån för att sedan avsluta med en bild av gruppernas karaktär. Innehållet i de olika kategorierna har vi valt att illustrera genom kortare citat från personalens diskussioner.

\section{Grupp 1}

- Reflekterande över förhållningssätt gentemot boende

Det fanns två inriktningar i de koder som sorterades in under denna kategori. Den ena handlade om reflektion över hur personalen tror att boende upplever deras olika bemötande.

Inom ramen för denna inriktning visade diskussionerna att personalen bemödade sig att försöka förstå: ... lätt att dra av dem täcket ... jag mår jättedåligt när jag ser någon ligga naken ... tänk att ligga där... . Diskussionerna visade också på upplevelsen av tidsbrist och hur det inverkar på arbetet med konsekvenser för bemötandet av boende: ... bråttom och integritet hör ihop... många gånger tänker jag hur blev det nu ... på toa ... i matsituationer ... vi står och stressar dem ... egentligen tar det bara längre tid ... . Även alternativa arbetssätt diskuterades för att förbättra situationen för boende: Vi ska kanske tänka på ... att gå ut när de ska göra sina behov ... att färre arbetar $i$ matsalen ... var och en kanske kan ta sin mat själv ... . Diskussionerna berörde också situationer när boenden beter sig olämpligt mot andra boenden: ... de sitter och pratar och skrattar àt någon annan som finns i rummet ... hur ska man tackla det?...

Den andra inriktningen handlade om hur personalen utfört sitt arbete utan att reflektera över sitt handlande. Inom ramen för denna inriktning ifrågasatte och reflekterade personalen över om de hade agerat på bästa sätt och sökte argument för det val som de gjort: ... jag kan tänka ... vad duktig jag var som klarade av att fä ner henne till den där aktiviteten ... men jag frågar mig just nu för vems skull egentligen? .... En annan diskussion handlade om en utsatt situation: ... han använde vaild mot oss ... vi var tvungna att hailla honom med alla krafter ... jag mådde jättedåligt efteråt ... hade vi använt mer våld än vad nöden krävde ... men vi kände att vi hade inget annat val ... min t-shirt var trasig så jag hade synliga bevis...

- Reflekterande över normer och värderingar

Denna kategori handlade om den personliga värdegrundens betydelse för utgångspunkter $\mathrm{i}$ arbetet: ... det handlar inte om våra egna personliga mål... utan om verksamhetens mål ... den är inte lika egoistisk. Du säger att du behandlar andra som du vill bli behandlad själv ... om man diskuterar det djupare ... så är det inte säkert att det passar alla som behöver din hjälp... .

Diskussionerna rörde också samhällets syn på äldre människor och hur det avspeglar sig inom det särskilda boendet, och hur det påverkar deras eget bemötande av boende: ... då boende flyttar in här ... ska 
de som in $i$ ett fack ... en tant som har page ... frissan visste inte hur hon skulle klippa ... alla ska ha permanent ... gå på gudstjänst ... om vi vet hur boende har haft det och vad de ansett viktigt ... så har det med integriteten att göra.

Diskussionsnivån i grupp ett bedömer vi som djup utifrån att personalen reflekterade kring egna erfarenheter med en tydlig koppling till manualens teoretiska innehåll. Personalgruppen visade en seriös, positiv förväntan och kamratlig stämning. Dess agerande utgjordes av lyhördhet, rak kommunikation och diskussionerna karaktäriserades av förmågan att ta upp känslomässigt svåra ämnen. Personalgruppens agerande kvarstod även om tre olika personalledare var inblandade. Personalledarnas agerande utgjordes av en avvaktande och defensiv hållning medan sjuksköterskan agerade offensivt och bidrog till en reflekterande diskussion.

\section{Grupp 2}

- Beaktande av boendes behov

I denna kategori diskuterades problemen med att boende inte alltid kan uttrycka sina önskningar och behov och personalens svårigheter att göra egna tolkningar om lämplig handling. Personalen verkade ha olika uppfattningar om hur de skulle förhålla sig, men med en gemensam utgångspunkt att bemöta den boende med respekt: ... boende styr vad vi gör ... berikande på det viset ... Även beaktandet av de boendes integritet berördes: ... svårt att veta om jag gjort övertramp eller ej ... . Personalen menade att de boende måste få ta eget ansvar och diskuterade olika sätt att ge stöd och handledning:
... problemet är att de tar inga egna initiativ ... jag försöker stötta dem ... det är det svåra ... har du ringt den och den?... .

- Närståendes betydelse

I kategorin diskuterades närståendes olika krav på hur arbetet borde utföras och att det påverkade personalen negativt: ... närstående anser att boende ska träna sig $i$ att göra lagad mat ... boende säger att han helst vill vara ensam efter jobbet, och då blir det ju snabbmat ... men på helgen blir det lagad mat ... jag känner mig stressad då kraven är så många ... . Samtidigt diskuterades betydelsen av att ha god kontakt med närstående: ... jag tycker att det fungerar som ... när närstående fär bra kontakt med oss personal då åker boende hem oftare... .

\section{- Den egna betydelsen}

Kategorin handlade om personalens upplevelse av att ha makt och insikten om att de boende är helt utlämnade till hur personalen tänker och agerar: ... ibland tänker jag att jag skulle kunna få boende att göra precis vad jag vill ... de litar på mig oavsett ... jag bestämmer om boende ska få veta sanningen, om han klarar av att höra den eller inte....

Grupp två bedömer vi har en medeldjup diskussionsnivå, utifrån att personalen reflekterade kring egna erfarenheter med försök att involvera diskussionsmanualens teoretiska innehåll, men de lyckades inte fullt ut nå denna ansats. Personalgruppen kännetecknades av en uppsluppen och förväntansfull stämning. Personalgruppens agerande utgjordes av "pratighet» och koncentrationssvårigheter, omväxlande med lyhördhet och struktur. Personalleda- 
ren deltog som en i gruppen och hennes agerande bestod av att hålla i struktur och påskynda diskussionen. Ingen sjuksköterska deltog. Denna diskussionsgrupp bestod av personal från tre olika enheter inom personalledarens ansvarsområde.

\section{Grupp 3}

• Förståelse för närstående

Kategorin handlade om problematiska möten med närstående där personalen förändrade sin handlingsstrategi efter att de hade blivit ifrågasatta: ... numera informeras närstående om boende måste flyttas till ett annat rum .... Innehållet visade också på försök att förstå närstående, där ord som ångest, skör och ömtålig ingick. Ett intresse i att vilja se problematiska möten utifrån de närståendes perspektiv lyftes också fram: ... missförstånd kan bero på att närstående bara ser delar av vairden ....

- Strategier mot boendes beteende

Kategorin handlade i huvudsak om situationer där personalen försökte hitta lösningar på påfrestande situationer: ... han slåss ju mycket ... vi har börjat dokumentera ... Hon är så orolig ... ska vi ge lite lugnande? ... Det går så långsamt ... det går fortare om vi klär på.... Samtalen hade även inslag som visade en medvetenhet om att personalens beteende påverkar boende: ... de känner om vi är stressade ....

Diskussionsnivån i grupp tre bedömer vi som ytlig utifrån att personalen inte diskuterade utan enbart konstaterade om de kände igen sig eller inte utifrån de frågeställningar som togs upp. Personalgruppen visade på en tyst och avvaktande stämning.
Personalledarens agerande utgjordes dels av en saklig dialog med sjuksköterskan, dels av "förhör» med övrig personal om hur arbetet utfördes. Sjuksköterskan hade en låg profil och bidrog inte till utvecklande av diskussionen. Gruppen inbjöds inte till diskussion i någon större utsträckning och agerade enbart med korta och ytliga inlägg. Vid den sista observationen uttryckte en av personalen att deltagandet i diskussionsgruppen inte hade givit henne något av värde, något som inte föranledde någon kommentar från övriga i gruppen.

\section{Grupp 4}

- Krav på närstående

I denna kategori uttrycktes behov av närståendeträffar i syfte att kräva arbetsinsatser av olika slag: ... närståendeträffar är nödvändiga ... att be dem märka kläder... följa med till sjukhuset ... ta med ett våffeljärn och hjälpa till ... . Det fanns även samtal som tog upp vikten av att närstående skulle informeras om personalens arbete med boende: ... man kan ju upplysa om att vi då och då har IVOR [Individuell vård-, omsorgs- och rehabiliteringsplanering, författarnas anmärkning] ... det vore intressant att höra hur de upplever målsättningen med boendes sociala omsorg och vaird ... .

- Attityder och förhållningssätt mellan personal

Kategorin innehöll korta inlägg som visade på rådande attityder och förhållanden mellan personalen: ... man känner sig nedvärderad av sjuksköterskan ... vi har ju fätt såret att läka förut ... vill jag lägga om såret så måste jag ju få det ... Vi är ju hus- 
mödrar ... den som står vid spisen ska vara där och andra ska inte lägga sig i ... Man behöver ju inte älska varandra för att man arbetar ihop ... Men vågar vi säga vad vi tycker ... Jag vågar då det ... Jag vet ej om jag vågar säga allt ... det är ju viktigt att säga förlåt... .

- Avvikande samtal

Innehållet i kategorin handlade om områden helt utanför det tema som skulle diskuteras till exempel hur andra arbetsplatser organiserat sitt arbete, samtal om telefoner, "stekpåsar" och musik på varuhus. En betydande del av samtalen ägnades till detta.

Diskussionsnivån i grupp fyra bedömer vi som ytlig och den kännetecknades av att personalen visade allt från ett konstaterande utifrån manualens frågeställningar till att gruppen diskuterade områden helt utanför. Personalgruppen präglades av en tryckt och avvaktande stämning. Dess agerande utgjordes av att personalen inte såg på eller lyssnade till varandra i någon större utsträckning. Personalledarens agerande speglade en osäkerhet som troligtvis hindrade utvecklingen av diskussionen. Sjuksköterskan bidrog med struktur och utveckling av diskussionen. Pesonalledare, sjuksköterska och några ur personalgruppen utryckte i enskilt samtal med observatören att det fanns en konflikt i omsorgsgruppen och att den diskussion som fördes var oärlig. Ingen vidrörde konflikten i diskussionsgruppen.

\section{Tolkning av gruppkultur -Bions gruppteori}

Resultatet visade att de i studien ingående grupperna var påtagligt olika till sin karaktär. Dessa olikheter är i överensstämmelse med våra personliga erfarenheter (jfr Kvale 1997) av att ha vistats i det rum där diskussionerna utspelades. Olikheterna visade sig genom att en grupp satsade på uppgiften, en annan grupp var ibland koncentrerad och ibland inte koncentrerad på uppgiften, en grupp fanns "troskyldigt" närvarande och slutligen visade en grupp på olika sätt att försöka undkomma uppgiften. I vår strävan efter att förstå dessa olikheter har vi funnit att Bions (1974) teori om gruppers kultur var både relevant och användbar. Gruppkultur i Bions mening innefattar den struktur gruppen uppnår i varje givet ögonblick, de verksamheter den bedriver och den organisation den antar (s 50). Bions gruppteori baseras på iakttagelser från terapigrupper men han menar att teorin även är giltig för arbetsgrupper. Vår förståelse har vuxit fram med hjälp av Bions tankar om två slag av psykisk aktivitet, arbetsgruppsaktivitet och grundantagandeaktivitet, som i växlande grad dominerar gruppens liv.

Grundantagandetillstånden kan ses som en drivkraft för förändring och fördjupad grupputveckling. I arbetsgruppsaktiviteten vet individerna sina roller och hur de kan bidra och föra gruppen framåt mot dess övergripande målsättning. Grupproblem och gruppspänningar medför att gruppen tenderar att regrediera och att irrationella processer kommer i förgrunden. Grundantagandetillståndet karaktäriseras av en 
irrationell gruppaktivitet, där hela gruppen agerar utifrån ett omedvetet "som-om»antagande. Detta antagande ligger till grund för vad gruppen kommer att anse vara riktigt och viktigt, det vill säga vad man gläds respektive förfäras över. Bion talar om tre olika grupptillstånd - "som-om" antaganden - nämligen beroende, flykt/kamp och parbildning (ibid).

\section{Gruppkultur som villkor för intervention}

Syftet med denna delstudie har varit att belysa diskussionsgruppernas kommunikation i relation till en intervention bestående av systematiska gruppdiskussioner. Som nämndes i inledningen ville vi använda observationsstudien för att se om den kunde vidga förståelsen för de marginella skillnaderna som utföll i de övriga delstudier. I den tolkning i termer av gruppkultur som görs i detta avsnitt har vi vävt in data från de intervjuer som genomfördes efter interventionen (Forsgärde et al manus, Westman et al manus). Detta är, som vi sett det, ett sätt att validera tolkningen genom ett slags trianguleringsförfarande (Bryman 1997).

Vi har valt att använda begreppet kultur i betydelsen gruppens beteende vid varje observation och resultatet visar att de fyra diskussionsgrupperna har olika kulturer och därmed olika förutsättningar för diskussionernas djup och innehåll. Gruppernas kultur kan i Bionska termer tolkas som arbetsgruppsaktivitet, arbetsgrupps/ parbildningsaktivitet, beroendeaktivitet och kamp/flyktaktivitet.

\section{Tabell I.}

Översikt över respektive grupps diskussionsinnehål, diskussionsnivå och kultur.

\begin{tabular}{|l|l|l|l|}
\hline $\begin{array}{l}\text { Diskussions- } \\
\text { grupp }\end{array}$ & Innehållskategori & $\begin{array}{l}\text { Diskussions- } \\
\text { nivå }\end{array}$ & Gruppkultur \\
\hline Grupp I & $\begin{array}{l}\text { Reflekterande över förhållningssätt } \\
\text { gentemot boende } \\
\text { Reflekterande över normer och värde- } \\
\text { ringar }\end{array}$ & Djup & $\begin{array}{l}\text { Arbetsgrupps- } \\
\text { aktivitet }\end{array}$ \\
\hline Grupp 2 & $\begin{array}{l}\text { Beaktande av boendes behov } \\
\text { Närståendes betydelse } \\
\text { Den egna betydelsen }\end{array}$ & Medel & $\begin{array}{l}\text { Arbetsgrupps-/ } \\
\text { parbildnings- } \\
\text { aktivitet }\end{array}$ \\
\hline Grupp 3 & $\begin{array}{l}\text { Förstående för närstående } \\
\text { Strategier mot boendes beteende }\end{array}$ & $\begin{array}{l}\text { Beroende- } \\
\text { aktivitet }\end{array}$ \\
\hline Grupp 4 & $\begin{array}{l}\text { Krav på närstående } \\
\text { Attityder och förhållningssätt mellan } \\
\text { personal } \\
\text { Avvikande samtal }\end{array}$ & $\begin{array}{l}\text { Kamp/flykt- } \\
\text { aktivitet }\end{array}$ \\
\hline
\end{tabular}

Definition av diskussionsnivå:

Ytlig = ett konstaterande utifrån frågeställningar/samtal om områden utanför manualen.

Medel = reflekterande utifrån egna erfarenheter med begränsad koppling till diskussionsmanualens teoretiska innehåll.

Djup = reflekterande utifrån egna erfarenheter med en tydlig koppling till diskussionsmanualens teoretiska innehåll.

Westman, Forsgärde \& Nygren: Gruppkultur som hinder och möjlighet för intervention ... 
De grupper som har tolkats ha betydande inslag av arbetsgruppsaktivitet, grupp 1 och 2, har enligt vår mening goda förutsättningar för att införliva interventionens budskap, som var att genomföra reflekterande samtal i syfte att mildra motsättningar inom personalgruppen. Personalens utsagor i grupp 1 får illustrera deras upplevelse av interventionen: Ja, jag har fätt aha-upplevelser...att man fätt tanken ... så där kan man ju också göra eller tänka det är ju lika riktigt ... . Dessa båda gruppers kultur präglas av en positiv känsla, hög motivation och en djup eller medeldjup diskussionsnivå. Diskussionernas huvudsakliga fokus var de boende och olika möjligheter diskuterades för att finna positiva lösningar på problematiska situationer. Grupperna diskuterade systematiskt utifrån varje frågeställning i manualen, reflekterade och försökte få insikt i varandras synsätt. Bion (1974:88) betonar att »i en arbetsgruppsaktivitet finns en medvetenhet om att gruppsamarbete är värdefullt, att den måste befatta sig med verkligheten och därmed utveckla rationella verktyg för att möta den".

I grupp 2 finns inslag av både arbetsgruppsaktivitet och grundantagandeaktivitet med tyngdpunkt på den förstnämnda. Vi tolkar att mottagligheten för interventionen i denna grupp var något mer begränsad än i grupp 1 dels utifrån den pendling mellan olika aktiviteter som förekom, dels utifrån diskussionernas innehåll och medeldjupa nivå. Personalens uttalande får illustrera deras upplevelse av interventionen: ... jag har försökt flera gånger ... påverka mina arbetskamrater så att de skulle kunna arbeta så här istället ... inte gå direkt på och säga att jag tycker att ni ska göra så här ... utan allmänt ... Oavsett om gruppen befann sig i arbetsgrupps- eller grundantagandetillstånd, präglades den av självständighet. Diskussionerna visade att de individuella målen för arbetet dominerade. Detta kan ses i ljuset av att personalen i stor utsträckning är ensamarbetande samt att de boende inte alltid kan uttrycka sina önskningar och viljeriktningar. Vid alla observationer genomsyrades gruppen av en hoppfull förväntan. När gruppen dominerades av parbildningsaktivitet synliggjordes "kotteribildningar" mellan personal som arbetade inom samma enhet. Övrig personal lyssnade stundtals ivrigt för att sedan bidra med sina synpunkter, de avbröt varandras inlägg, diskussionen var av generell karaktär och uttrycktes ofta i klichéer. Bion (1974:56) menar »att gruppen lever genom paret i hopp om att de ska lösa gruppens alla problem, att paret skapar en idé eller något annat åt de övriga. Gruppen tolererar denna situation och förefaller, även om man utbyter menande leenden vara beredd att låta paret fortsätta hur länge som helst. Undantag från detta finns, då övriga individer i gruppen också måste ha en hel del de skulle vilja säga».

De två grupper som kännetecknades av grundantagandeaktivitet, grupp 3 och 4, är enligt vår mening inte i någon större utsträckning mottagliga för interventionens budskap. Personalens uttalande får illustrera deras upplevelse av interventionen. Först ett exempel från grupp 3: ... ska jag vara ärlig så har jag hört det förut ... det har varit som repetition.... I grupp 4 fanns följande exempel: ... Vår diskussion är inte riktigt ärlig ... men det verkar inte gå att 
göra något åt ... det finns olika uppfattningar i gruppen... en personal är mycket dominant och ska bestämma ... . Bion (1974) menar att grupper som befinner sig i ett grundantagandetillstånd inte är mottagliga för påverkan. Dessa gruppers aktivitet präglas av en avvaktande och tyst (grupp 3) eller tryckt (grupp 4) stämning. Samtalen i grupp 4 hade en negativ prägel med fokus på strategier riktade mot boendes beteende och krav på närståendes insatser i syfte att underlätta det egna arbetet.

I den grupp där vi såg de tydligaste tecknen på beroende, grupp 3 , tog personalen inget egentligt ansvar för innehåll och utfall i samtalen. Personalledaren ställde konkreta frågor om arbetets innehåll och utformning där personalen »snällt» besvarade dessa och bekräftade sin personal med ord som: ... ni är ju så duktiga ... . Ingen synlig reaktion hos personalen kunde noteras. Samtalen kännetecknades genomgående av ett neutralt förhållningssätt. Sammanfattningsvis hade personalledaren i denna grupp en, som vi uppfattade, mekanisk utgångspunkt i manualen. Till exempel lästes en av manualens frågeställningar upp med följdfrågor som: ... hur gör ni? ... inte har vi väl det så här hos oss? ... . Frågorna besvarades mycket kortfattat och vidare diskussion uteblev. Bion (1974:67, 70, 115) betonar att i beroendeaktivitet är det någon person som tillfredsställer gruppens behov, övrigas läge är att få sina behov tillfredsställda. Gruppen ser ledaren som den enda person som är värd att lyssna på samtidigt som den med sitt beteende visar att den inte tror att hon kan sin sak. Bion menar vidare att var och en i gruppen har relationer med ledaren som i sig skapar spänningar. Lorentzon
(1999) hävdar att man behöver inte vistas i en sådan grupp länge förrän man inser att gruppen är indragen i en säregen maktkamp.

I den grupp där kamp/flyktaktivitet var dominerande, grupp 4, utgjordes samtalen av en ytlig, negativ och kravfylld prägel och de avslutas inte fullt ut utan nödvändiga beslut "hänger i luften«. Till stor del berörde samtalen avvikande teman vilket stämmer väl överens med Bions (1974) teori som beskriver att gruppen inte samlas för att utföra ett kreativt arbete utan det är gruppens enade kamp/flyktaktivitet som är det centrala, individernas behov kommer i andra hand (s 58). Personalledarens, sjuksköterskans och omsorgspersonalens beteende tydde på försök att försena sammankomsten och diskussionen. Detta förevisades till exempel genom att gruppdiskussionerna inte började på utsatt tid och att ingen lokal var bokad. Bion (1974: 58) menar att kamp/flyktgruppen kan till exempel småprata, komma för sent och ägna sig åt oräkneliga andra sysselsättningar för att kringgå uppgiften. Alla var inte aktiva och kommunikationen i gruppen präglades av återhållsamhet, tillbakavisande och icke-bekräftelse. Några medlemmar i gruppen påtalade att det fanns en konflikt bland omsorgspersonalen. Bion (1974) konstaterar att motsättningarna och konflikterna i en kamp/flyktgrupp mer eller mindre är konstanta.

Enligt Bion (1974:120) så sker det en ständig pendling mellan arbetsgruppsaktivitet och grundantagandeaktivitet i alla grupper. Grundantagandetillstånd bör inte ses som något negativt per definition, utan kan förstås som ett led i gruppers utveck- 
ling där arbetsgruppsaktiviteten tar hem spelet i det långa loppet (s 120). En möjlig påverkan av intervention finns åtminstone så länge pendlingen pågår. Däremot bör man vara uppmärksam på om det sker en stagnation i grundantagandeaktiviteten. Vårt empiriska underlag i detta avseende ger inte underlag för slutsatsen att stagnation förekommit i någon av grupperna.

Den tolkning av observationerna som vi har valt är givetvis en av många möjliga tolkningar. Det har varit enkelt att placera in de studerade gruppernas karaktär i den Bionska begreppsapparaten, och vi menar att den analys vi gjort ger oss möjlighet att bättre förstå vilka effekter (eller uteblivna sådana) som blev följden av interventionen med systematiska diskussionsgrupper.

\section{Gruppkulturen och utfallet av systematiska gruppdiskussioner}

Studien visar att gruppkulturen är av betydelse för diskussionernas djup och innehåll och att den därmed kan ses som en förutsättning för interventions utfall. Resultatet visar att i de grupper som kännetecknas av arbetsgruppsaktivitet, grupp 1 och 2, fanns goda förutsättningar för att genomförandet av systematiska diskussionsgrupper var en bra form av stödjande insats för att skapa en ömsesidig förståelse och utveckla samarbetet i personalgrupperna. Vi menar att diskussioner och reflektioner i dessa grupper medförde en djupare förståelse och en ökad kunskap som föreföll påverka relationerna positivt. Resultatet visar också att de grupper som kännetecknades av grundantagandeaktivitet (grupp 3 och 4) inte i någon större utsträckning hade förutsättningar att tillgodogöra sig interventionens budskap. Där förefaller ytterligare eller andra stödinsatser vara nödvändiga.

En utgångspunkt för denna delstudie var, som nämndes inledningsvis, att de övriga delstudierna vi genomfört och som baseras på enkät (Forsgärde et al 2000) och intervjuer som genomfördes med personal före och efter interventionen (Forsgärde et al 2002, Forsgärde et al manus, Westman et al manus, Westman et al manus) visade marginella, vaga eller subtila förändringar. Hur kan vi förstå detta med hjälp av den delstudie som har redovisats här? Med tanke på att två av grupperna visade sig ha goda förutsättningar borde vi ha fått ett mer påtagligt utfall i de andra delstudierna. En delförklaring till detta kan vara att vi i övriga delstudier valt att analysera diskussionsgrupperna som en helhet (EG) och att gruppernas olikheter därmed "tar ut varandra». En annan förklaring kan vara att grupperna 1 och 2 redan före interventionen var relativt väl fungerande och att en förändring från ett skapligt bra arbetsklimat till ett gott inte gav något större utslag i varken enkätmaterial eller intervjuer. Slutligen kan även kontextuella och strukturella faktorer varit av betydelse som neutraliserat utfallet av interventionen. I denna delstudie där vi har valt att analysera respektive diskussionsgrupp (1-4) var för sig framträder olikheter i grupperna. En poäng är att studien visar att dessa olikheter har ett kvalitativt innehåll som uppenbarligen påverkar mottagligheten för den intervention som genomfördes.

Vi kan sammantaget formulera slutsatsen i termer av att för att nå målet att 
utveckla och därmed förbättra förståelsen mellan professionsgrupperna, förefaller gruppkulturerna (jfr Winship \& Hardy 1999) och personalens upplevelse av deltagandet i gruppen vara av betydelse (jfr Platzer et al 2000). Sammanfattningsvis kan vi konstatera att gruppkulturerna haft bety- delse för interventionens utfall. Vi menar $i$ likhet med Berg (2000) att innan liknande gruppbaserade stödåtgärder genomförs bör man värdera möjligheterna att lyckas utifrån en kännedom om de gruppkulturer som råder i de grupper som man avser påverka.

\section{Litteratur}

Armelius, Bengt-Åke \& Fogelstam, Hans (1992) Utvärdering av miljöterapi med hjälp av en Bion-skala. Umeå Universitet: Institutionen för tillämpad psykologi. Tips:rapport 44.

Adler, Patricia \& Adler, Peter (1994) Observational techniques i Denzin, NK. \& Lincoln, YS., red,: Handbook of qualitative research. California: SAGE publications.

Altschul, A. (1964) Group dynamics and nursing care. International Journal of Nursing Studies, 1, 151-158.

Berg, Agneta (2000) Psychiatric nurses' view of nursing care, clinical supervision and individualised care. Interventions on a dementia and on a general psychiatric ward. Lund University: Department of Nursing the Medical Faculty, No 4 .

Bion, Wilfred (1974) Gruppterapi. Teorier om erfarenheter. Stockholm: Bokförlaget Prisma.

Bryman, Alan (1997) Kvantitet och kvalitet $i$ samhällsvetenskaplig forskning. Lund: Studentlitteratur.

Burnard, Philip (1991) A method of analysing interview transcripts in qualitative research. Nurse Education Today, 11, 461-466.

Cheney, George \& Thoger, Christensen, L. (2000) Organizational identity. Linkages between internal and external communication i Jablin, Fredric, M. \& Putnam, Linda, L., ed,: The new handbook of organizational communication. Advances in theory, research and methods. London: Sage Publications.
Cook, Stephen \& Matheson, Helen (1995) Teaching group dynamics: a critical evaluation of an experimental programme. Nurse Education Today, 17, 31-38.

Corey, Gerald, Corey, Marianne, S. \& Callanan, Patrick (1998) Issues and ethics in the helping professions. Pacific Grove: Brooks Cole.

Forsgärde, Marianne, Westman, Berith \& Nygren, Lennart (2000) Ethical discussion groups as an intervention to improve the climate in the interprofessional work with the elderly and disabled. Journal of Interprofessional Care, 14, 351-361.

Forsgärde, Marianne, Westman, Berith \& Jansson, Lilian (2002) Professionals carers' struggle to be confirmed. Narratives within the care off elderly and disabled. Scandinavian Journal of Caring Sciences, 16, 12-18.

Forsgärde, Marianne, Westman, Berith, Jansson, Lilian \& Norberg, Astrid. Qualitative changes in staff narratives after an intervention, in dwellings for elderly people and for people with disabilities. Manuscript.

Haddock, Jane (1996) Reflection in groups: contextual and theoretical considerations within nurse education and practice. Nurse Education Today, 17, 381-385.

Hartley, Jean, F. (1996) Intergroup relations in organizations i West, Michael ed,: Handbook of work group psychology. England: John Wiley \& Sons Ltd.

Holme, Idar, M. \& Solvang, Bernt, K. (1991) Forsk-

Westman, Forsgärde \& Nygren: Gruppkultur som hinder och möjlighet för intervention ... 
ningsmetodik om kvalitativa och kvantitativa metoder. Lund: Studentlitteratur.

Jablin, Fredric, M. (1992) Formal organization structure i Jablin, Fredric, M., Putman, Linda, L., Roberts, Karlene, H. \& Porter, Lyman, W., ed,: Handbook of organizational communication. An interdisciplinary perspective. London: Sage publications.

Jablin, Fredric, M. \& Putnam, Linda, L., ed,: (2000)

The new handbook of organizational communication. Advances in theory, research and methods. London: Sage Publications.

Jablin, Frederic, M. \& Sias, Patricia, M. (2000) Communication competence i Jablin, Fredric, M. \& Putnam, Linda, L., red,: Handbook of organizational communication. An interdisciplinary perspective. London: Sage Publications.

Kvale, Steinar (1997) Den kvalitativa forskningsintervjun. Lund: Studentlitteratur.

Lorentzon, Lars (1999) Vredens pedagogik. Stockholm: Bjurner och Bruno.

Netting, Ellen \& Williams, Frank (1996) Case Manager-Physician collaboration. Implications for professional identity, roles and relationship. Health \& Social Work, 21:3, 216-224.

Miles, Matthew \& Huberman, Michael (1994) Qualitative data analysis. California: Sage.

Norberg, Astrid, Udén, Giggi \& Andrén, Signe (1998) Physicians' registered nurses' and enrolled nurses' stories about ethically difficult episodes in the care of older patients. European Nurse, 3, 3-13.

Morgan, David (1993) Qualitative content analysis: A guide to paths not taken. Qualitative health research, 3, 112-121.

Olsson, Erik (1998) På spaning efter gruppens själ. Gruppen i teori och praktik. Lund: Studentlitteretur.

Patton, Michael, Q. (1990) Qualitative evaluation and research methods. Newbury Park, London and New Delhi: Sage.

Platzer, Hazel, Blake, David \& Ashford, Dorothy (2000) Barriers to learning from reflection: a study of the use of group work with post-registration nurses. Journal of Advanced Nursing, 31, 1001-1008.
Polit, Denise \& Hungler, Bernadette (1999) Nursing research, principles and methods. Philadelphia: JB. Lippincott Company.

Poulton, BC. (1995) Effective multi-disciplinary teamwork in primary health care. PhD thesis. Sheffield: University of Sheffield.

Proposition 1990/91:14. Ansvaret för vård och service till äldre och handikappade. Stockholm: Riksdagens Utredningstjänst.

Socialstyrelsen 1996:2. Ädelreformen slutrapport. Stockholm: Socialstyrelsen.

SOU 1997:51. Brister i omsorg: en fråga om bemötande av äldre. Stockholm: Fritze.

Stein, Mark (1996) Unconscious phenomena in work. i West, Michael, A. (1996) Handbook of work group psychology. New York: John Wiley \& Sons Ltd.

Svensson, Per-Gunnar \& Starrin, Bengt (1996) Kvalitativa studier $i$ teori och praktik. Lund: Studentlitteratur.

Westman, Berith, Forsgärde, Marianne, Jansson, Lilian \& Norberg, Astrid. Problematic situations in everyday work within the professional care of elderly people and people with disabilities. Manuscript.

Westman, Berith, Forsgärde, Marianne, Jansson, Lilian \& Norberg, Astrid. Problematic situations in everyday work - staff experience within the care of the elderly and people with disability after an intervention. Manuscript.

Wilmot, Stephen (1995) Professional values and interprofessional dialogue. Journal of Interprofessional Care, 9, 257-266.

Wilson, Julie \& While, Alison (1998) Methodological issues surrounding the use of vignettes in qualitative research. Journal of Interprofessional Care, 12, 79-87.

Winship, G. \& Hardy, S. (1999) Disentangling dynamics: group sensitivity and supervision. Journal of Psychiatric and Mental Health Nursing, 6, 307-312.

Wood, N., Farrow, D. \& Elliott, B. (1994) A review of primary health care organisation. Journal of Clinical Nursing, 3, 243-250. 


\section{Summary}

\section{Group culture: obstacle or opportunity for intervention in professional conflicts?}

\section{A study of social and nursing care staff who work with elderly people and people with disability}

This article is about four staff groups with training in social and nursing care who participated in systematic discussion groups for seven to fifteen months. The goal was to create a platform of mutual understanding to foster cooperation between the different staff categories. Each discussion group was observed in action for six to nine hours. After analysis it was clear that the receptiveness of the discussion groups to intervention differed based on variations in group culture found in the individual groups. In the results, two groups were identified as having work group activity (Bion 1974) in which intervention appears to be an appropriate supportive initiative. Two other groups were identified as having basic assumption activity (Bion 1974) that did not appear to be particularly receptive to the message of the intervention, requiring additional supportive measures. In other complementary studies based partly on questionnaires before and after intervention (Forsgärde et al 2000), and partly on analysis of interviews conducted with staff before and after intervention (Forsgärde et al 2002; Forsgärde et al, manuscript; Westman et al, manuscript, Westman et al, manuscript), the discussion groups were considered as a whole and the studies showed marginal changes that could only be linked to the intervention with great uncertainty. After separate analysis of each group, major similarities became apparent during this study. A partial understanding of marginal differences found in other complementary studies could be because two of the four groups were not especially receptive to the intervention message. In summary, group culture appears to be of great significance to the outcome of the intervention, and it is therefore important to pay attention to culture of the staff groups before the intervention is implemented. 